\title{
Collection development of electronic information resources in Turkish university libraries 放
}

\author{
Yașar Tonta* \\ Department of Library Science, Hacettepe University, 06532 Beytepe, Ankara, Turkey
}

\begin{abstract}
The number of information sources available through both printed and electronic media are ever increasing. Even libraries with sizable collection development budgets are having difficulties in coping with this increase. Yet with the development of new technologies, the possibilities of innovative interlibrary cooperation projects emerge: libraries combining their efforts through various consortia are trying to get access to electronic information sources more economically. In this paper, we briefly review the state-of-the-art of Turkish university libraries and summarize the efforts to set up a university library consortium to provide consortial access to electronic information sources and services. We discuss some of the causes which are delaying the establishment of such a consortium. (C) 2001 Elsevier Science Ltd. All rights reserved.
\end{abstract}

\section{Introduction}

Cooperation occurs when two or more libraries work together to provide more developed services to their respective users [1]. The emphasis in this definition should be on providing more developed services. Yet cooperation is often perceived as libraries with considerably richer resources helping the less fortunate ones. Cooperation "for the sake of cooperation" rarely works, however. Cooperation aims to carry out projects that an individual library cannot do so by itself such as providing consortial access to electronic information resources. The main thrust of cooperation is that libraries should enjoy the benefits of cooperation by providing better, faster and cheaper services. Put differently, if an individual library could

is This is a revised version of a paper delivered at the 66th IFLA Council and General Conference, 13-18 August 2000, Jerusalem, Israel.

* Corresponding author.

E-mail address: tonta@hacettepe.edu.tr (Y. Tonta). 
provide the same service or product to its users faster, cheaper and with less effort than the cooperative schemes require, then there will be no incentive for libraries to cooperate.

The proliferation of electronic information services and products, and increasing availability of information processing, storage and communication technologies in libraries facilitated the sharing of resources and engendered new cooperative schemes. Moreover, librarians increasingly feel that they must cooperate to reap the benefits of "economics of scale" [2]. In traditional resource sharing schemes, libraries possessing the physical materials tend to benefit more from the cooperative collection development efforts. However, the availability of networked information resources encouraged libraries to streamline their cooperative collection development efforts. Possessing electronic information resources does not prohibit other libraries' access to information. This has facilitated cooperative collection development efforts and further encouraged libraries to set up library consortia to provide more and varied electronic resources through the networks and to increase their bargaining power with publishers of electronic information resources [3].

Turkish university libraries are also trying to set up a consortium to share electronic information resources. Along with the establishment of the National Academic Network and Information Center (ULAKBİM) in 1996, the academic library community concentrated their efforts on providing electronic information services to academia. This paper reviews the current consortial collection development efforts of Turkish university libraries and discusses some of the underlying issues which need to be resolved.

\section{Why should we cooperate?}

"Information" is a national resource and the lifeblood of national development. It is as crucial for organizations, corporations and nations to gain competitive advantage as it is important to get access to current, up-to-the-minute information to survive in the global market. Therefore, production, acquisition, organization, retrieval and use of information should be seen as a national issue. As information becomes an indispensable resource and commodity in the "Information Era," providing information services is of paramount importance to all types of organizations. The cost of providing effective information services is on the rise in parallel with the increasing role that information plays in day-to-day activities of organizations. Yet, librarians are faced with the challenge of providing better services with shrinking budgets. Fortunately, the developments in information technology (IT) create new opportunities for librarians. For instance, librarians can now provide access to networked information sources that their libraries do not even own. They need to weigh the virtues of new approaches such as "access versus ownership." They try to cater to ever-increasing information needs of their clientele through various networks such as the Internet. Interlibrary cooperation and coordination of resource sharing is also facilitated in the network environment as it is easier for libraries to form consortia and share electronic information resources.

As indicated earlier, traditional resource sharing arrangements sometimes encouraged competition rather than cooperation in view of the benefits that relatively large libraries accrued by owning research materials. This is no longer the case, however. Small libraries 
can get access to information sources over the network with the same speed as the large ones can, regardless of where the physical sources are held. Furthermore, introduction of new pricing models by publishers such as licensing (rather than subscription) and access fees for electronic information sources and relatively favorable offers for consortial agreements has made the economics of cooperation more visible. This does not necessarily mean that librarians have all the wherewithal to tackle such issues as access management and long-term preservation and archiving of electronic information in consortial collection development schemes. Nevertheless, in terms of satisfying information needs of their users, they are in a much better position in the new environment than they were before.

\section{Overview of Turkish university libraries}

Although the history of the development of Turkish universities dates back to the $15^{\text {th }}$ century, the development of modern university libraries occurred only in 1950s when the Middle East Technical University (METU) was founded in 1956 in Ankara. METU Library was the first library that was based on American campus system, thereby providing central library services for all students and faculty alike.

Currently, there are some 70 public and private universities in Turkey. The existing academic library services are not satisfactory, however. University library collections and budgets are rather limited. For instance, the total number of items held in all university libraries is around five million, which is much less than what an average American university library owns. Almost one third of university libraries own fewer than 500 periodical titles.

The limited university library collections and services are a product of chronic budget shortages. The proportion of library budgets to the university budgets range between $0.2 \%$ and $3.8 \%$, average being $0.7 \%$. The total amount of money allocated to all university libraries in 1999 was just a little over 10 million US dollars. In contrast, annual operational expenses of Harvard University Libraries is around 60 million US dollars [4]. The average university library budget was about $\$ 200.000$ in the same year. There has been a great divide between libraries of developed and developing universities in terms of average expenditure per student. Developed university libraries spend as much as 37 times more money per student than that of newly established ones. The number of university libraries with budgets exceeding one million US dollars was only four (METU, Bilkent, Bosphorus and Istanbul Technical University libraries). It should be noted that figures cited here include expenses for buying library materials as well as for all the other items (excluding personnel). Needless to say, such scarce budgets are not even enough to buy "core" library materials and maintain core periodical titles, let alone develop electronic information collections.

\section{Interlibrary cooperation in Turkish university libraries}

Despite such meager budgets and collections, university libraries in Turkey tend to keep separate subscriptions to relatively expensive periodical titles. For instance, in 1997 we studied the subscription overlap rate for 30 journal titles costing more than $\$ 5000$ apiece 
among four libraries (ULAKBİM, Bilkent, METU and Hacettepe libraries) located within the periphery of about five kilometers [5]. One library (ULAKBİM) paid some $\$ 250.000$ for all 30 titles while the other three paid the following amounts: $\$ 186.000$ for 21 titles, $\$ 154.000$ for 18 titles, and $\$ 63.000$ for 7 titles. In other words, the duplication rates of libraries in pairs ranged between $23 \%$ and $70 \%$ ! It should be noted that some of those expensive titles had logged very few uses during the year. Considering that these libraries are geographically close to each other, it is difficult to understand what it is that prohibited them from cooperating, at least in the acquisition of the most expensive titles in their collections. The situation is no different for bibliographic databases on CD-ROMs

We see the lack of coordination in the acquisition of networked information resources too. A few years ago, university libraries started to subscribe, individually rather than through a library consortium, to networked databases and electronic journals that are available through the Internet. They seem to have neglected the fact that electronic information resources are most amenable to central acquisition and storage. Several libraries located in different geographic regions throughout the country can easily get access to such resources through the Internet. Providing distributed access to Web-based databases and electronic journals became more economical than keeping their printed and/or CD-ROM copies. For instance, the library director of the Koç University in Istanbul reports that only $12 \%$ of the bound periodical volumes in the Library circulated in 1999. The average cost per search made by the Koç users on Academic Search Elite database (Ebsco) was as low as 15 cents. "In contrast to this, the average cost per search on all cd-roms was \$15 and was as high as \$25 on ISI's Science Citation Index" [6]. Considering the additional costs for storage and handling of print journals, this is but one strong case against the idea of ownership.

\section{Networking infrastructure of Turkish universities}

Sharing networked information sources through distributed access appears to be more economical. Yet, doing so requires a sound networking infrastructure. Most Turkish university libraries lacked internal and external networking capabilities up until a few years ago. However, the proliferation of Web-based sources eased the networking requirements somewhat as libraries no longer have to set up their internal CD-ROM local area networks, for example. Still, sharing networked information sources on a national scale necessitates more than just access to the Internet.

The National Academic Network and Information Center (ULAKBIM) was founded in June 1, 1996 in Ankara by the Turkish Scientific and Technical Research Center (TÜBİTAK). It took over the responsibilities of the Turkish Network of Universities and Research Institutions (TÜVAKA) and the Higher Education Council Documentation Center. ULAKBIM first set up a 34Mbps national academic network (ULAKNET) which is based on ATM (asynchronous transmission mode) and frame relay technologies. It became operational in the first half of 1997. Currently, almost all universities are connected to the ULAKNET backbone (between Ankara, İstanbul and İzmir) with speeds ranging from $64 \mathrm{Kbps}$ to $4 \mathrm{Mbps}$. ULAKNET has access to international networks in the USA (NSFNET) 
and Europe (TERENA: Trans-European Academic and Research Networking Association), although the capacity of international ports (over 40Mbps) is somewhat limited.

In addition to setting up the national academic network, ULAKBİM is also responsible for developing a "vision" of the electronic library to satisfy the information needs of academia and for setting up the organizational structure to implement and maintain this vision. ULAKNET was a first step in the right direction as the network soon became the test bed for sharing electronic information sources among university libraries.

\section{Initiatives to set up an academic library consortium}

The term "library consortium" can be defined as an association composed of several member libraries. It has its own structure of governance and can act as a corporate body on behalf of all its members. Cooperative collection development, sharing physical resources through document delivery services and provision of access to electronic information sources are among the main purposes of setting up a library consortium. Hundreds of local, regional and national library consortia are operational throughout the world. These consortia came together in 1997 and set up an umbrella organization called the International Coalition of Library Consortia (ICOLC). ICOLC provides consultancy services to Coalition members and recently published a statement on selection and acquisition of electronic information sources [7].

The idea of setting up an academic library consortium in Turkey was suggested by ULAKBIM during the first meeting of one of its Advisory Boards (28 February 1997). ULAKBIM initiated the first Web-based union catalog of periodicals by combining the catalogs of ULAKBİM, METU, Bilkent and Hacettepe University libraries in Ankara and made it available through its web site in 1997. Also, ULAKBIM secured a trial period with Academic Press (AP) for its IDEAL (International Digital Electronic Access Library) database containing the full-texts of the articles appeared in 174 journals published by AP. The abovementioned libraries had a chance to get access to the IDEAL database during 1997 and tested it.

In order to discuss the feasibility of establishing an academic library consortium more thoroughly, ULAKBİM organized a full-day meeting in Ankara (November 14, 1997) and invited all the deputy rectors (responsible for libraries) and library directors of Turkish universities. Some 115 delegates participated in this meeting. It was agreed that electronic information resources and services be provided to all Turkish university students and faculty through the national academic network (ULAKNET), that a task force be set up by ULAKBIM to review library consortia providing similar services in other countries and to review the technical, financial and organizational feasibility of establishing an academic library consortium in Turkey. An electronic discussion list called "isbirligi" (cooperation) was set up on the ULAKBIM server for this purpose.

The infrastructure to provide electronic information services to all universities through the national academic network was completed by ULAKBIM during the first half of 1998 . ULAKBIM bought needed hardware and software to store electronic information sources (servers and date warehouses) and set up proxy servers to provide networked services. A 
draft bylaw stating the mission, objectives, governance and work principles of the consortium was discussed in one of the Advisory Board meetings (28 February 1998). No agreement was reached, however, as potential members maintained differing views on the governance and financing of the consortium. The main issues to tackle appeared to be securing the initial investment (circa $\$ 10$ million) to set up the consortium and the difficulties that university libraries were likely to experience in transferring monies to the consortium budget. Although the financial backing of the Higher Education Council (HEC) was sought and discussions with universities were continued during the year (1998), ULAKBIM was not able to secure the initial investment to license the electronic resources and convince other universities to form a consortium.

ULAKBIM's efforts to set up a consortium were stalled during the year, however, as TÜBITTAK, ULAKBIM's parent organization, questioned its commitment to the project. SilverPlatter's ERL (Electronic Reference Library) database and ISI's Web of Science were planned for network access on a trial basis in 1998. Yet the actual trial of those sources took place in late 1999 after ULAKBIM introduced its VEDES (Hosting Databases and Electronic Journals) project. By the time the trial took place, it was clear that ULAKBIM was no longer eager to coordinate the consortial efforts, although it promised to become a member of, and provide technical support to, the consortium if and when it is set up. This is in contrast to its mission which stated that ULAKBİM will not only set up and maintain the national academic network but also provide universities networked access to electronic information sources through consortial arrangements. In addition, ULAKBIM considered the "constitution of the rules of cooperation" as its main task, too [8].

On the other hand, on November 6, 1998, the director of the METU Library sent a letter to major university libraries in which he summarized his views on library consortium and invited them to meet. Throughout 1999, representatives of METU, Bilkent, Hacettepe, and Gazi University libraries (ULAKBIM joined them later), together with representatives of such companies as Swets, Lange \& Springer, and EBSCO met several times to discuss the possibility of forming a consortium (ANKOS) consisting of university libraries in Ankara (later in Turkey). Bilkent, Bosphorus, Çukurova, Dokuz Eylül, Aegean, Gazi, Hacettepe, İstanbul Technical, Koç, METU, Sabancı University libraries and ULAKBİM agreed to become ANKOS members and tried to identify the information products and services that they wish to license on a consortial basis.

Although the official charter of ANKOS has not been found formally, the ANKOS members continued to meet periodically to discuss the possibilities of securing consortial deals with the publishers and vendors of electronic content. For example, they received bids from Academic Press, EBSCO, and the American Mathematical Society during 1999. Furthermore, they signed individual agreements with those vendors for IDEAL, EBSCOHost and MathSciNet databases, respectively, in November 1999. Vendors appeared to recognize member libraries' efforts and reduced the prices for individual license agreements. Different university libraries opted for different databases. For example, a group of five libraries signed a license agreement with Academic Press to get Web access to IDEAL containing full text of 174 journals. Another group of five university libraries signed a deal with EBSCO for Academic Search Elite and Business Source Premier databases containing abstracting and indexing information for more than 2000 journals as well as full text of more than 1000 
journals. Seven university libraries joined MathSciNet to get Web access to full text of more than 1.4 million articles. Publishers and vendors allowed IP-based unlimited access to their databases in all three agreements [9]. Some 20 ANKOS members signed an agreement with the Institute for Scientific Information for its Web of Science database for the year 2000. Currently ANKOS members are continuing discussions with publishers such as Kluwer Online, Springer-Link, Elsevier ScienceDirect and Zentralblatt für Mathematik databases.

\section{Issues and problems}

As our brief summary shows, Turkish university libraries are trying to expand their electronic information sources and services through consortial agreements with publishers and vendors, even though no formal consortium is in place yet. What follows is a brief list of issues and problems, in no particular order, that Turkish university libraries should tackle in order to streamline their cooperative and consortial efforts:

- Culture of working together to carry out cooperative projects;

- Commitment to cooperation;

- Mutual understanding;

- Consensus building;

- Patience;

- Skills in planning, organization and administration;

- Knowledge;

- Human resources;

- Monetary resources; and

- Common intelligence.

We are well aware that each issue listed above merits a separate discussion in itself and can be a subject of another paper. Suffice it to say that it is of vital importance for Turkish university libraries to overcome these difficulties and join forces together to provide better electronic information services to their users. Acting alone will benefit no one as most university libraries lack needed resources (monetary and otherwise). In order for effective use of national resources, institutions (such as State Planning Organization, Higher Education Council and TUBITAK) and individuals (such as university administrators, librarians, researchers and users) should carry out their duties to the full extent of their capacities. Only then can electronic information services of Turkish university libraries flourish.

\section{References}

[1] Boisse JA. Library cooperation: a remedy but not a panacea. IFLA Journal 1995;21(2):89.

[2] Economies of scale are defined as decreasing average costs while increasing the number, volume, and size of products/operations.

[3] Tonta Y. Kütüphanelerarası işbirliği ve bilgi kaynaklarının etkin kullanımı (Interlibrary cooperation and effective use of information resources). In: Kütüphanecilik Bölümü 25. Yll'a Armağan (100-108) Ed. Bülent Yılmaz. Ankara: H.Ü. Kütüphanecilik Bölümü, 1997. 
[4] Odlyzko A. (1997 August). The economics of electronic journals. First Monday [Online], 2(8). Available at: http://www.firstmonday.dk/issues/issue2_8/odlyzko/index.html [12.08.1999].

[5] Tonta Y. Kütüphanelerarası işbirliğinin neresindeyiz? (The state-of-the-art of interlibrary cooperation). In: Bilginin Serüveni: Dünü, Bugünü ve Yarın . . (493-514). Bayram Ö, et al., editors. Ankara: Turkish Library Association, 1999.

[6] Lindley JA. Strategic issues in electronic librarianship. Bilgi Dünyasi 2000;1(2):334.

[7] International Coalition of Library Consortia (ICOLC). Statement of current perspective and preferred practices for the selection and purchase of electronic information. [Online]. Available at: http://www. library.yale.edu/consortia/statement.html [15.09.1999], 1998.

[8] Türk Yüksekögrretim Sistemi: 1994-1995'den 1995-1996'ya Geliṣmeler (Turkish Higher Education System: Developments from 1994-1995 to 1995-1996). Ankara: Higher Education Council, 1997, p. 86.

[9] Özbag C. Üniversitelerarasi Konsorsiyum calismalarina bir örnek: ANKOS (ANKOS: Turkish University Libraries Consortium). Paper presented at the 36th Library Week, Ìzmir, 31 March 2000. 